\title{
The Association of
}

\section{Methylenetetrahydrofolate Reductase Genotypes with the Risk of Childhood Leukemia in Taiwan}

\author{
Jen-Sheng Pei ${ }^{1 \oplus}$, Chin-Mu Hsu${ }^{2 \oplus}$, Chia-Wen Tsai ${ }^{2,30}$, Wen-Shin Chang ${ }^{2,4}$, Hong-Xue $\mathrm{Ji}^{2,4}$, \\ Chieh-Lun Hsiao ${ }^{2}$, Chia-En Miao ${ }^{2}$, Yuan-Nian Hsu ${ }^{5}$, Da-Tian Bau ${ }^{2,3,4}$ * \\ 1 Department of Pediatrics, Taoyuan General Hospital, Ministry of Health and Welfare, Taoyuan, Taiwan, \\ ROC, 2 Terry Fox Cancer Research Laboratory, China Medical University Hospital, Taichung, Taiwan, ROC, \\ 3 Graduate Institute of Basic Medical Science, China Medical University, Taichung, Taiwan, ROC, \\ 4 Graduate Institute of Clinical Medical Science, China Medical University, Taichung, Taiwan, ROC, \\ 5 Department of Family Medicine, Taoyuan General Hospital, Ministry of Health and Welfare, Taoyuan, \\ Taiwan, ROC \\ จ These authors contributed equally to this work. \\ *artbau1@yahoo.com.tw
}

\section{OPEN ACCESS}

Citation: Pei J-S, Hsu C-M, Tsai C-W, Chang W-S, Ji H-X, Hsiao C-L, et al. (2015) The Association of Methylenetetrahydrofolate Reductase Genotypes with the Risk of Childhood Leukemia in Taiwan. PLoS ONE 10(3): e0119776. doi:10.1371/journal. pone. 0119776

Academic Editor: Olivia Fletcher, The Institute of Cancer Research, UNITED KINGDOM

Received: June 28, 2014

Accepted: February 3, 2015

Published: March 20, 2015

Copyright: @ 2015 Pei et al. This is an open access article distributed under the terms of the Creative Commons Attribution License, which permits unrestricted use, distribution, and reproduction in any medium, provided the original author and source are credited.

Data Availability Statement: All relevant data are within the paper.

Funding: This study was supported by research grants from the Terry Fox Cancer Research Foundation of China Medical University Hospital and Taoyuan General Hospital, Ministry of Health and Welfare, Taoyuan, Taiwan, ROC (grant number: PTH10332) and Taiwan Ministry of Health and Welfare Clinical Trial and Research Center of Excellence (MOHW104-TDU-B-212-113002). The funders had no role in study design, data collection

\section{Abstract}

\section{Background}

Acute lymphoblastic leukemia (ALL) is the most prevalent type of pediatric cancer, the causes of which are likely to involve an interaction between genetic and environmental factors. To evaluate the effects of the genotypic polymorphisms in methylenetetrahydrofolate reductase (MTHFR) on childhood ALL risk in Taiwan, two well-known polymorphic genotypes of MTHFR, C677T (rs1801133) and A1298C (rs1801131), were analyzed to examine the extent of their associations with childhood ALL susceptibility and to discuss the MTHFR genotypic contribution to childhood ALL risk among different populations.

\section{Methodology/Principal Findings}

In total, 266 patients with childhood ALL and an equal number of non-cancer controls recruited were genotyped utilizing PCR-RFLP methodology. The MTHFR C677T genotype, but not the A1298C, was differently distributed between childhood ALL and control groups. The CT and TT of MTHFR C677T genotypes were significantly more frequently found in controls than in childhood ALL patients (odds ratios $=0.60$ and $0.48,95 \%$ confidence intervals $=0.42-0.87$ and $0.24-0.97$, respectively). As for gender, the boys carrying the MTHFR C677T CT or TT genotype conferred a lower odds ratio of 0.51 (95\% confidence inter$\mathrm{val}=0.32-0.81, \mathrm{P}=0.0113$ ) for childhood ALL. As for age, those equal to or greater than 3.5 years of age at onset of disease carrying the MTHFR C677T CT or TT genotype were of lower risk (odds ratio $=0.43$ and $95 \%$ confidence interval $=0.26-0.71, P=0.0016$ ). 
and analysis, decision to publish, or preparation of the manuscript.

Competing Interests: The authors have declared that no competing interests exist.

\section{Conclusions}

Our results indicated that the MTHFR C677T T allele was a protective biomarker for childhood ALL in Taiwan, and the association was more significant in male patients and in patients 3.5 years of age or older at onset of disease.

\section{Introduction}

Acute lymphoblastic leukemia (ALL) is now the most common form of pediatric leukemia, accounting for $25-30 \%$ of all childhood malignancies [1]. The annual incidence rate worldwide of childhood ALL is approximately 10 cases per 100,000, with peak incidence occurring at approximately 2 to 5 years of age [2]. While the clinical, pathological and immunophenotypic features of the disease are well documented, the etiology of ALL has not been fully clarified [1]. In the literature, certain environmental factors (i.e., ionizing radiation, parental use of alcohol and tobacco, and virus exposure) have been identified as potential risk factors for the development of childhood ALL, but only ionizing radiation has been confirmed thus far [3]. However, several lines of evidence now suggest that genetic factors may play a significant role in the development of childhood ALL. For instance, inherited genetic disorders, such as Down syndrome and Fanconi anemia, have been associated with an enhanced ALL risk [4, 5]. Additionally, genetic mutations in several cancer-related genes, such as $p 53, \mathrm{~N}$-ras, and PHF6, have frequently been identified in ALL patients [6]; and finally, only a small fraction of children who are exposed to environmental factors go on to develop ALL, indicating the potential for a genetic predisposition to develop childhood ALL.

To reveal the environmental and genomic factors together with the interactions among them is useful for evaluation and prevention of cancer risk. It is believed that one group of the candidate genes are those encoding enzymes related to the metabolism of identified carcinogens. Among these genes, methylenetetrahydrofolate reductase (MTHFR) is a folatemetabolism enzyme in charge of the conversion of 5, 10-methylene-tetrahydrofolate into 5-methyltetrahydrofolate, homocysteine remethylation, and biosynthesis of DNA and RNA [7]. The regulatory effects of MTHFR on DNA methylation, DNA replication, DNA repair and cell division make MTHFR a potential candidate for a cancer-predisposition gene. It is reasonable that rapidly proliferating malignancies have a higher requirement for DNA synthesis and could be more susceptible to folate deficiency and resultant DNA damage. Low dietary folate and MTHFR deficiency induced the formation of intestinal tumors in a BALB/c mice model [8].

Previous investigations of MTHFR variations focused on the catalytic domain and the two polymorphisms, C677T (rs1801133) and A1298C (rs1801131), which may determine its enzymatic activity $[9,10]$. In the case of the C677T polymorphism, the cytosine base at position 677 changes to a thymidine base, which in turn affects the amino acid at position 222, as it is changed from alanine to valine. The MTHFR enzyme TT variants from the polymorphism become thermo labile, resulting in a loss of its activity with elevated temperature [11]. The modified protein loses its flavin adenine dinucleotide cofactor more quickly and has a lower stability. The mutation effect can be suppressed by the addition of folate, which causes a higher flavin adenine dinucleotide affinity and an increase in MTHFR stability [11]. The MTHFR A1298C polymorphism is localized in the coding regulatory domain [12]. In the literature, it was reported that heterozygotes and rare homozygotes of MTHFR C677T variant exert $60 \%$ and $30 \%$ of wild-type enzyme activity, respectively [10]. As for A1298C, the rare homozygous have $60 \%$ of wild-type activity [10]. In 2004, it was found that cancer cells which expressed 
677T MTHFR were of lower activity than those express 677C MTHFR. Also the expression of mutant MTHFR 677T would increase the sensitivity of cancer cells to the cytotoxicity of 5FU. In null mice model, the expression of 677T MTHFR enhanced the growth rates of xenografts than those expressed wild-type 677C MTHFR. Consistent with the evidence observed in cell models, the $677 \mathrm{~T}$ xenografts were more sensitive to $5 \mathrm{FU}$ treatment than those of $677 \mathrm{C}$ in mice model [13]. Many studies investigating the MTHFR variant have found positive associations with solid cancers, such as colorectal cancer [14], breast cancer [15], oral cancer [16, 17], and lung cancer [18].

Over the past decade, there has been a growing interest in the possible association between folate-related polymorphisms and the risk of developing lymphoid malignancies, including childhood ALL. First, Skibola [19] and Matsuo [20] in 1999 and 2001, respectively, reported that people with variant MTHFR genotypes had a significantly lower susceptibility to adult ALL and malignant lymphoma. In the same period, Franco [21] and Wiemels [22] provided similar pilot results for pediatric leukemia. The purpose of this study, therefore, was to analyze the genetic polymorphisms of both MTHFR C677T and A1298C in a representative pediatric population sample (control/case $=266 / 266$ ), to investigate the correlation between MTHFR genotypes and childhood ALL in Taiwanese children, and to then summarize all of the relevant updated literature.

\section{Materials and Methods}

\section{Study population and sample collection}

Our study was approved by the Institutional Review Board of China Medical University Hospital, and written informed consent was obtained from one or both the parent of all participants. Two hundred and sixty-six patients diagnosed with childhood ALL (all patients under 18 years of age) were recruited between Apr 2005 to Jan 2010 from the general surgery outpatient clinics within the Pediatric Departments at China Medical University Hospital and National Taiwan University Hospital, Taiwan, Republic of China. All of the clinical characteristics of these ALL patients, including their histological details, were identified by expert surgeons. All subjects voluntarily participated, completed a questionnaire with the help of parents or guardians and provided peripheral blood samples. The questionnaires recorded their disease history, diet and sleep lifestyles and the disease history, diet and behavioral lifestyle, social-economic status of the parents. An equal number of age-matched non-cancer healthy volunteers were selected for use as a control group following initial random sampling from the Health Examination Cohort established from Apr 2005 to Jan 2010 as previously published [23]. The registered health practitioners in the hospital provide a multidisciplinary team approach of health assessment for the volunteers. Most of the volunteers underwent health examinations every 5 to 6 months. A total of 457 volunteers age under 18 years were recruited into this study and chosen were cancer free by the age at diagnosis of the case child with the International Classification of Disease, ninth revision (ICD-9) codes. Finally, 266 participants were included for analysis in the study since we have to match the population structure (number, age and gender) with our case population. The overall agreement rate in the study was above $85 \%$.

\section{Genotyping assays}

Genomic DNA was prepared from peripheral blood leukocytes using a QIAamp Blood Mini Kit (Blossom, Taipei, Taiwan), long-term stored at $-80^{\circ} \mathrm{C}$, diluted and aliquotted for genotyping as working stock at $-20^{\circ} \mathrm{C}$ [23-25]. Genotyping for MTHFR C677T and A1298C of all subjects was carried out by polymerase chain reaction restriction fragment length polymorphism (PCR-RFLP) assays as previously published [17, 25-27]. The primers for MTHFR C677T were 
forward 5' - TGA AGG AGA AGG TGT CTG CGG GA-3' and reverse 5'- AGG ACG GTG CGG TGA GAG TG-3'. The primers for MTHFR A1298C were forward 5'- GGG AGG AGC TGA CCA GTG CAG-3' and reverse 5'- GGG GTC AGG CCA GGG GCA G-3'. The underlined $\mathrm{C}$ mismatched base in the forward primer were used to create a partial Fnu4H I cutting site, which will be completed in the presence of the $\mathrm{C}$ allele at the A1298C polymorphic site. The following cycling conditions were performed: $5 \mathrm{~min}$ of initial denaturation at $95^{\circ} \mathrm{C}, 35 \mathrm{cy}-$ cles of $30 \mathrm{sec}$ of denaturation at $95^{\circ} \mathrm{C}, 30 \mathrm{sec}$ of annealing at $54^{\circ} \mathrm{C}$ and $1 \mathrm{~min}$ of elongation at $72^{\circ} \mathrm{C}$, and $7 \mathrm{~min}$ of final extension at $72^{\circ} \mathrm{C}$. The 198-bp PCR product of MTHFR C677T and 138-bp PCR product of MTHFR A1298C were subject to enzyme digestion with Hinf I and Fnu4H I (New England, Biolabs, Beverly, MA USA), respectively for $4 \mathrm{~h}$ and then visualized by ethidium bromide-stained 3\% agarose gel electrophoresis under UV light. On digestion with Hinf I, the PCR product of MTHFR C677T arising from the C allele was uncut (198 bp), whereas the $\mathrm{T}$ allele was cut into fragments of $175 \mathrm{bp}$ and $23 \mathrm{bp}$. On digestion with Fnu4H I, the PCR product of MTHFR A1298C arising from the A allele was uncut (138 bp), whereas the $\mathrm{C}$ allele was cut into fragments of $119 \mathrm{bp}$ and $19 \mathrm{bp}[17,25,27]$. The success rate of PCR-RFLP is $100 \%$, and the genotypes of five percent of the participants in both the control and patient groups were analyzed by PCR direct sequencing (Genomics BioSci \& Tech Co., Taipei). The consistency between direct sequencing and PCR-RFLP was 100\%.

\section{Statistical analyses}

Only those participants having both genotypic and clinical data (control/case $=266 / 266$ ) were selected for final analysis. The descriptive statistics of patients and controls were presented as the mean and standard deviations (SDs) or as percentages. The Pearson's chi-square test or Fisher's exact test (when any cell was less than five) was used to compare the distribution of the genotypes. Associations were expressed and evaluated as odds ratios (ORs) with $95 \%$ confidence intervals (95\%CIs). Interactions between the genotypes and onset age or gender were examined by using the likelihood ratio test. Statistical tests were deemed significant when the $P$-value was less than 0.05 . All statistical analysis were performed with SAS 9.2 and SPSS 17 .

\section{Results}

The frequency distributions for the age and gender of 266 childhood ALL patients and 266 non-cancer controls are shown in Table 1 . The characteristics of the patients and controls were well matched $(P>0.05)$ (Table 1$)$.

The genotype frequencies for the MTHFR C677T and A1298C in the controls and childhood ALL patients are shown in Table 2. The genotype frequencies of the two MTHFR SNPs of the controls were in Hardy-Weinberg Equilibrium ( $p=0.9007$ and 0.8886 , respectively). The genotypic frequency distributions for MTHFR C677T were significantly different between childhood ALL and control groups $(P=0.0076)$, while those for the A1298C polymorphism were not significantly different $(P>0.05)$ (Table 2$)$. Those who carried CT, TT, CT or TT genotypes had significantly reduced risk of ALL with ORs of $0.60,0.48$, and 0.58 respectively compared to those with the CC genotype (95\% CI $=0.42-0.87,0.24-0.97$ and $0.41-0.82$, respectively). The conclusion that can be deduced from Table 2 is that the MTHFR C677T T allele seems to be a protective biomarker for childhood ALL in Taiwan.

Because age and gender are the predominant risk factors for developing childhood ALL, the interactions between the MTHFR genotype and age and gender were further analyzed and presented in Table 3. The average age of onset for the $133^{\text {rd }}$ and $134^{\text {th }}$ subjects in the control and patient groups was 3.5 years; thus, we further stratified the groups into $<3.5$ and $\geq 3.5$ year-old subgroups. Noticeably, in the elder ( $\geq 3.5$ years) group, subjects with CT or TT genotypes for 
Table 1. Demographic data of 266 childhood ALL patients and 266 controls.

\begin{tabular}{|c|c|c|c|c|c|c|c|}
\hline \multirow[t]{2}{*}{ Characteristic } & \multicolumn{3}{|c|}{ Controls $(n=266)$} & \multicolumn{3}{|c|}{ Patients $(n=266)$} & \multirow[t]{2}{*}{$p$-value ${ }^{a}$} \\
\hline & $\mathbf{n}$ & $\%$ & Mean (SD) & $\mathbf{n}$ & $\%$ & Mean (SD) & \\
\hline Age (years) & & & $8.3(4.8)$ & & & $7.0(4.4)$ & 0.64 \\
\hline Gender & & & & & & & 1.00 \\
\hline Boy & 148 & $55.6 \%$ & & 148 & $55.6 \%$ & & \\
\hline Girl & 118 & $44.4 \%$ & & 118 & $44.4 \%$ & & \\
\hline
\end{tabular}

a Based on a chi-square test.

doi:10.1371/journal.pone.0119776.t001

MTHFR C677T had lower risks for developing childhood ALL than those with the homozygous CC genotype ( $P$ for trend $=0.0016, \mathrm{OR}=0.48$ and $0.22, \mathrm{CI}=0.28-0.80$ and $0.07-0.69$ for $\mathrm{CT}$ and TT, respectively); however, this was not the case for the younger $(<3.5$ years $)$ group (Table 3). As for gender, boys with CT or TT genotypes for MTHFR C677T were less likely to develop childhood ALL than those with the homozygous CC genotype ( $P$ for trend $=0.0113$, $\mathrm{OR}=0.54$ and $0.32, \mathrm{CI}=0.33-0.89$ and $0.11-0.94$ for CT and TT, respectively), but this was not the case for the girls (Table 3). In summary, analyses revealed an interaction between the age of onset and gender among MTHFR C677T genotypes in the childhood ALL susceptibility ( $P$ values for interaction $=0.0378$ and 0.2524 for $\geq 3.5$ years versus $<3.5$ years and girls versus boys, respectively).

\section{Discussion}

ALL is more common among children than adults. Among the patients, the precursor B subtype accounted for approximately $75 \%$ to $90 \%$ of the cases, while the remaining $10 \%$ to $25 \%$ were precursor $\mathrm{T}$ lymphoblastic leukemia [2]. Lymphocytic leukemia cells are rapidly dividing cells that require higher folate supplementation and are more vulnerable to folate deficiency. Previous research has demonstrated that maternal folate supplementation during pregnancy can be effective in reducing the risk of childhood ALL in babies [28]. The two most common

Table 2. Distribution of the MTHFR genotypes among 266 childhood ALL patients and 266 controls.

\begin{tabular}{|c|c|c|c|c|c|c|}
\hline Genotype & Controls & $\%$ & Cases & $\%$ & $P$-value ${ }^{a}$ & OR $(95 \% \mathrm{Cl})^{\mathrm{b}}$ \\
\hline C677T rs1801133 & & & & & $0.0076 *$ & \\
\hline $\mathrm{CC}$ & 134 & $50.4 \%$ & 169 & $63.5 \%$ & & 1.00 (Reference) \\
\hline CT & 109 & $41.0 \%$ & 83 & $31.2 \%$ & & $0.60(0.42-0.87)^{*}$ \\
\hline TT & 23 & $8.6 \%$ & 14 & $5.3 \%$ & & $0.48(0.24-0.97) *$ \\
\hline $\mathrm{CT}+\mathrm{TT}$ & 132 & $49.6 \%$ & 97 & $36.5 \%$ & & $0.58(0.41-0.82) *$ \\
\hline A1298C rs1801131 & & & & & 0.8984 & \\
\hline$A A$ & 171 & $64.3 \%$ & 168 & $63.2 \%$ & & 1.00 (Reference) \\
\hline$A C$ & 85 & $32.0 \%$ & 86 & $32.3 \%$ & & $1.03(0.71-1.49)$ \\
\hline $\mathrm{CC}$ & 10 & $3.7 \%$ & 12 & $4.5 \%$ & & $1.22(0.51-2.90)$ \\
\hline $\mathrm{AC}+\mathrm{CC}$ & 95 & $35.7 \%$ & 98 & $36.8 \%$ & & $1.05(0.74-1.50)$ \\
\hline
\end{tabular}

a Based on Pearson's chi-square test

${ }^{\mathrm{b}}$ OR: odds ratio; $\mathrm{Cl}$ : confidence interval

* Statistically significant

doi:10.1371/journal.pone.0119776.t002 
Table 3. Distribution of the MTHFR C677T and A1298C genotypes stratified by age and gender

\begin{tabular}{|c|c|c|c|c|c|c|c|c|c|c|c|}
\hline \multirow{3}{*}{ Characteristics } & \multicolumn{5}{|c|}{ MTHFR C677T } & \multirow{3}{*}{ Characteristics } & \multicolumn{5}{|c|}{ MTHFR A1298C } \\
\hline & Controls & Cases & $P_{\text {trend }}{ }^{\mathrm{a}}$ & $P_{\text {inter }}{ }^{\mathrm{b}}$ & OR $(95 \% \mathrm{Cl})^{\mathrm{c}}$ & & Controls & Cases & $P_{\text {trend }}{ }^{\mathrm{a}}$ & $P_{\text {inter }}{ }^{\mathrm{b}}$ & OR (95\% \\
\hline & n (\%) & n (\%) & & & & & n (\%) & n (\%) & & & \\
\hline \multicolumn{6}{|l|}{ Onset age } & \multicolumn{6}{|l|}{ Onset age } \\
\hline \multicolumn{3}{|l|}{$<3.5$ years } & 0.5812 & 0.0378 & & $<3.5$ years & & & 0.8519 & NS & \\
\hline $\mathrm{CC}$ & $\begin{array}{l}70 \\
(52.63)\end{array}$ & $\begin{array}{l}78 \\
(58.65)\end{array}$ & & & $\begin{array}{l}1.00 \\
\text { (Reference) }\end{array}$ & $\mathrm{AA}$ & $\begin{array}{l}83 \\
(62.41)\end{array}$ & $\begin{array}{l}86 \\
(64.66)\end{array}$ & & & $\begin{array}{l}1.00 \\
\text { (Reference) }\end{array}$ \\
\hline CT & $\begin{array}{l}53 \\
(39.85)\end{array}$ & $\begin{array}{l}45 \\
(33.83)\end{array}$ & & & $\begin{array}{l}0.76(0.46- \\
1.27)\end{array}$ & $A C$ & $\begin{array}{l}44 \\
(33.08)\end{array}$ & $\begin{array}{l}40 \\
(30.08)\end{array}$ & & & $\begin{array}{l}0.88(0.52- \\
1.48)\end{array}$ \\
\hline TT & $10(7.52)$ & $\begin{array}{l}10 \\
(7.52)\end{array}$ & & & $\begin{array}{l}0.90(0.35- \\
2.28)\end{array}$ & $\mathrm{CC}$ & $6(4.51)$ & $7(5.26)$ & & & $\begin{array}{l}1.13(0.36- \\
3.49)\end{array}$ \\
\hline $\mathrm{CT}+\mathrm{TT}$ & $\begin{array}{l}63 \\
(47.37)\end{array}$ & $\begin{array}{l}55 \\
(41.35)\end{array}$ & & & $\begin{array}{l}0.78(0.48- \\
1.27)\end{array}$ & $\mathrm{AC}+\mathrm{CC}$ & $\begin{array}{l}50 \\
(37.59)\end{array}$ & $\begin{array}{l}47 \\
(35.34)\end{array}$ & & & $\begin{array}{l}0.91(0.55- \\
1.50)\end{array}$ \\
\hline \multicolumn{3}{|l|}{$\geq 3.5$ years } & \multicolumn{3}{|l|}{$0.0016 *$} & $\geq 3.5$ years & & & 0.7370 & & \\
\hline $\mathrm{CC}$ & $\begin{array}{l}64 \\
(48.12)\end{array}$ & $\begin{array}{l}91 \\
(68.42)\end{array}$ & & & $\begin{array}{l}1.00 \\
\text { (Reference) }\end{array}$ & AA & $\begin{array}{l}88 \\
(66.16)\end{array}$ & $\begin{array}{l}82 \\
(61.65)\end{array}$ & & & $\begin{array}{l}1.00 \\
\text { (Reference) }\end{array}$ \\
\hline CT & $\begin{array}{l}56 \\
(42.11)\end{array}$ & $\begin{array}{l}38 \\
(28.57)\end{array}$ & & & $\begin{array}{l}0.48(0.28- \\
0.80)^{*}\end{array}$ & $A C$ & $\begin{array}{l}41 \\
(30.83)\end{array}$ & $\begin{array}{l}46 \\
(34.59)\end{array}$ & & & $\begin{array}{l}1.20(0.72- \\
2.02)\end{array}$ \\
\hline TT & $13(9.77)$ & $4(3.01)$ & & & $\begin{array}{l}0.22(0.07- \\
0.69)^{*}\end{array}$ & $\mathrm{CC}$ & $4(3.01)$ & $5(3.76)$ & & & $\begin{array}{l}1.34(0.35- \\
5.17)\end{array}$ \\
\hline $\mathrm{CT}+\mathrm{TT}$ & $\begin{array}{l}69 \\
(51.88)\end{array}$ & $\begin{array}{l}42 \\
(31.58)\end{array}$ & & & $\begin{array}{l}0.43(0.26- \\
0.71)^{*}\end{array}$ & $A C+C C$ & $\begin{array}{l}45 \\
(33.84)\end{array}$ & $\begin{array}{l}51 \\
(38.35)\end{array}$ & & & $\begin{array}{l}1.22(0.74- \\
2.01)\end{array}$ \\
\hline \multicolumn{6}{|l|}{ Gender } & \multicolumn{6}{|l|}{ Gender } \\
\hline \multicolumn{3}{|l|}{ boys } & $0.0113 *$ & NS & & boys & & & 0.7082 & NS & \\
\hline $\mathrm{CC}$ & $\begin{array}{l}76 \\
(51.35)\end{array}$ & $\begin{array}{l}100 \\
(67.57)\end{array}$ & & & $\begin{array}{l}1.00 \\
\text { (Reference) }\end{array}$ & AA & $\begin{array}{l}96 \\
(64.86)\end{array}$ & $\begin{array}{l}90 \\
(60.81)\end{array}$ & & & $\begin{array}{l}1.00 \\
\text { (Reference) }\end{array}$ \\
\hline CT & $\begin{array}{l}60 \\
(40.54)\end{array}$ & $\begin{array}{l}43 \\
(29.05)\end{array}$ & & & $\begin{array}{l}0.54(0.33- \\
0.89)^{*}\end{array}$ & $A C$ & $\begin{array}{l}47 \\
(31.76)\end{array}$ & $\begin{array}{l}51 \\
(34.46)\end{array}$ & & & $\begin{array}{l}1.16(0.71- \\
1.89)\end{array}$ \\
\hline TT & $12(8.11)$ & 5 (3.38) & & & $\begin{array}{l}0.32(0.11- \\
0.94)^{*}\end{array}$ & $\mathrm{CC}$ & $5(3.38)$ & $7(4.73)$ & & & $\begin{array}{l}1.49(0.46- \\
4.88)\end{array}$ \\
\hline $\mathrm{CT}+\mathrm{TT}$ & $\begin{array}{l}72 \\
(48.65)\end{array}$ & $\begin{array}{l}48 \\
(32.43)\end{array}$ & & & $\begin{array}{l}0.51(0.32- \\
0.81)^{*}\end{array}$ & $\mathrm{AC}+\mathrm{CC}$ & $\begin{array}{l}52 \\
(35.14)\end{array}$ & $\begin{array}{l}58 \\
(39.19)\end{array}$ & & & $\begin{array}{l}1.19(0.74- \\
1.91)\end{array}$ \\
\hline girls & & & 0.3565 & & & girls & & & 0.9130 & & \\
\hline $\mathrm{CC}$ & $\begin{array}{l}58 \\
(49.15)\end{array}$ & $\begin{array}{l}69 \\
(58.47)\end{array}$ & & & $\begin{array}{l}1.00 \\
\text { (Reference) }\end{array}$ & $\mathrm{AA}$ & $\begin{array}{l}75 \\
(63.56)\end{array}$ & $\begin{array}{l}78 \\
(66.10)\end{array}$ & & & $\begin{array}{l}1.00 \\
\text { (Reference) }\end{array}$ \\
\hline CT & $\begin{array}{l}49 \\
(41.53)\end{array}$ & $\begin{array}{l}40 \\
(33.90)\end{array}$ & & & $\begin{array}{l}0.69(0.40- \\
1.18)\end{array}$ & $A C$ & $\begin{array}{l}38 \\
(32.20)\end{array}$ & $\begin{array}{l}35 \\
(29.66)\end{array}$ & & & $\begin{array}{l}0.89(0.51- \\
1.55)\end{array}$ \\
\hline TT & $11(9.32)$ & $9(7.63)$ & & & $\begin{array}{l}0.69(0.27- \\
1.77)\end{array}$ & $\mathrm{CC}$ & $5(4.24)$ & $5(4.24)$ & & & $\begin{array}{l}0.96(0.27- \\
3.46)\end{array}$ \\
\hline $\mathrm{CT}+\mathrm{TT}$ & $\begin{array}{l}60 \\
(50.85)\end{array}$ & $\begin{array}{l}49 \\
(41.53)\end{array}$ & & & $\begin{array}{l}0.69(0.41- \\
1.15)\end{array}$ & $\mathrm{AC}+\mathrm{CC}$ & $\begin{array}{l}43 \\
(36.44)\end{array}$ & $\begin{array}{l}40 \\
(33.90)\end{array}$ & & & $\begin{array}{l}0.89(0.52- \\
1.53)\end{array}$ \\
\hline
\end{tabular}

doi:10.1371/journal.pone.0119776.t003 
SNPs of the MTHFR gene may determine MTHFR enzyme activity and the availability of folate to the whole body and may ultimately be linked to childhood ALL risk. For this reason, we investigated their relationships with the susceptibility to developing childhood ALL in Taiwan. We found that the T variant genotypes of MTHFR C677T were significantly associated with a lower susceptibility to childhood ALL (Table 2). These findings are consistent with previous research that identified the $\mathrm{T}$ allele to be a protective factor [21, 22, 29-36], but not with those studies which identified the $\mathrm{T}$ allele as a risk factor [37-39]. Additionally in some studies the $\mathrm{T}$ allele has been shown to have no association with childhood ALL [40-54]. Table 4 contains a summary of the findings from all of the literature investigating the association between MTHFR genotypes and childhood leukemia risk with a representative sample size (control/case larger than 70/70) and a non-redundant population. Among the studies, allele $\mathrm{T}$ was associated with decreased risk in populations of Taiwan, Serbia, China, Netherlands, Greece, Canada, and UK [22, 30-32, 34, 36], while with increased risk in populations of India [38]. Others proposed that the T allele was not associated with childhood ALL [40-54]. However, even the people in the same country, for instance Brazil, there was a dramatically different susceptibility to cancer, showing both decreased [21,35] and increased risk [37]. In India, the same inconsistency could be observed $[38,39,42,45]$. This kind of inconsistency may be mainly caused by different genetic background and environmental exposure status in addition to sampling bias. Therefore, all the molecular epidemiologists are revealing the genomic and environmental factors contribute to childhood ALL. The limited sample sizes in childhood ALL, compared to studies using larger amounts of samples collected among patients of common cancers, may be one of the factors contributing to inconsistent conclusions. For the low incidence of childhood ALL, this is unavoidable. In a current meta-analysis investigating the contributions of MTHFR C677T and A1298C genotypes to childhood ALL, it was demonstrated that the T allele of MTHFR C677T was associated with a lower risk of childhood ALL in both Asians and Caucasians, while A1298C was not observed to have any effect [55]. The current study was the first to utilize a Taiwanese sample, and the relationship was consistently positive for MTHFR C677T and negative for A1298C (Table 2).

We have further analyzed the relationship between the C677T genotype and childhood ALL risk according to the subject age and gender. Interestingly, the interaction between MTHFR C677T and age is clear; specifically children $\geq 3.5$ years old at age of onset of disease with a CT or TT genotype had a lower risk of childhood ALL than those with the CC genotype. This relationship was not found for the group of children $<3.5$ years old at age of onset of disease (Table 3). Additionally, no such age difference was observed in analyses of the A1298C genotype. In 2013, Jiang and his colleagues extended the Meta-analysis to 37 individual studies investigating adult ALL. They found that TT genotype was associated with a lower risk of ALL $(\mathrm{OR}=0.776,95 \% \mathrm{CI}: 0.687-0.877, p<0.001)$. After stratification by ethnicity, the significance only existed among Caucasians ( $\mathrm{OR}=0.715,95 \%$ CI: $0.655-0.781, p<0.001$ ), at borderline among Asian (OR $=0.711,95 \% \mathrm{CI}$ : $0.591-1.005, p=0.055)$, but not among others (OR = 0.913, 95\% CI: 0.656-1.271, $p=0.590$ ) [56]. The mechanisms of MTHFR involved in the etiopathology of and progression of ALL may be different for adults and children. Although no statistically significance was found in the girls-only analysis in Table 3, there is a similar trend to that observed for the boys (Table 3). The enlarged sample size may provide more realistic answer. Thus, as for the different contribution of MTHFR genotypes to ALL susceptibility between boys and girls, further investigations are in urgent need. In the literature, studies have revealed significant differences in the serum or plasma folate levels among people with various C677T genotypes, but not among those with various A1298C genotypes [57, 58]. Further measurement and analysis of the folate levels among children of different ages, together with their diet intake of folic acid, may help us to better understand the etiology. 
Table 4. Summary of the original international literature investigating the association of the MTHFR C677T genotypes with childhood leukemia.

\begin{tabular}{|c|c|c|c|c|c|c|}
\hline First author & Ref \# & Year & Population & $\begin{array}{l}\text { Controls } \\
\text { (n) }\end{array}$ & $\begin{array}{l}\text { Cases } \\
\text { (n) }\end{array}$ & Association and highlights \\
\hline Pei & $\begin{array}{l}\text { Current } \\
\text { study }\end{array}$ & 2014 & Taiwan & 266 & 266 & $\begin{array}{l}\text { Allele T associated with lower risk, especially in boys gender and the age } \\
\text { population who were equal to or elder than } 3.5 \text { years old }\end{array}$ \\
\hline $\mathrm{Li}$ & 54 & 2014 & China & 93 & 98 & No association \\
\hline Silva & 37 & 2013 & Brazil & 390 & 177 & Allele T associated with higher risk \\
\hline Amigou & 40 & 2012 & France & 1681 & 764 & No association \\
\hline Azhar & 41 & 2012 & Iran & 109 & 72 & No association \\
\hline Nikbakht & 42 & 2012 & India & 100 & 125 & No association \\
\hline Chan & 29 & 2011 & Indonesia & 177 & 185 & $\begin{array}{l}\text { Specific haplotypes of MTHFR C677T and A1298C (C-C \& T-A) } \\
\text { associated with a reduced risk }\end{array}$ \\
\hline Metayer & 43 & 2011 & 35 countries & 448 & 377 & No association \\
\hline Damnjanovic & 30 & 2010 & Serbia & 412 & 78 & Allele T associated with lower risk \\
\hline Lightfoot & 44 & 2010 & UK & 824 & 939 & No association \\
\hline Sadananda & 45 & 2010 & India & 99 & 86 & No association \\
\hline Sood & 38 & 2010 & India & 255 & 95 & Allele T associated with higher risk \\
\hline Tong & 31 & 2010 & China & 508 & 361 & Allele T associated with lower risk \\
\hline Yeoh & 46 & 2010 & $\begin{array}{l}\text { Chinese/ } \\
\text { Malay }\end{array}$ & 756 & 531 & No association \\
\hline de Jonge & 32 & 2009 & Netherlands & 496 & 245 & Allele T associated with lower risk \\
\hline Alcasabas & 47 & 2008 & Philippines & 394 & 189 & No association \\
\hline Kamel & 33 & 2007 & Egypt & 311 & 88 & $\begin{array}{l}\text { Specific haplotypes of MTHFR C677T and A1298C (677CT and 1298AC) } \\
\text { associated with a reduced risk }\end{array}$ \\
\hline Petra & 48 & 2007 & Slovenia & 258 & 68 & No association \\
\hline Kim & 49 & 2006 & Korea & 100 & 66 & No association \\
\hline Chatzidakis & 34 & 2006 & Greece & 88 & 52 & Allele T associated with lower risk \\
\hline Reddy & 39 & 2006 & India & 142 & 135 & $\begin{array}{l}\text { Allele } C \text { associated with lower risk, and male children more susceptible to } \\
\text { ALL }\end{array}$ \\
\hline Zanrosso & 35 & 2006 & Brazil & 199 & 176 & Allele T associated with lower risk \\
\hline Oliveira & 50 & 2005 & Portugal & 111 & 103 & No association \\
\hline Schnakenberg & 51 & 2005 & Germany & 379 & 443 & No association \\
\hline Thirumaran & 52 & 2005 & Germany & 1472 & 460 & No association \\
\hline Krajinovic & 36 & 2004 & Canada & 330 & 270 & Allele $T$ associated with lower risk \\
\hline Wiemels & 22 & 2001 & UK & 200 & 253 & Allele T associated with lower risk \\
\hline Franco & 21 & 2001 & Brazil & 71 & 71 & Allele T associated with lower risk \\
\hline
\end{tabular}

Note: Some studies that had less than 70 cases and 70 controls of a redundant population were not included.

The survey of literature was updated 2014/09/18.

doi:10.1371/journal.pone.0119776.t004

We also tested for a gender-dependent effect on determining childhood susceptibility to ALL. The protective impact of the T allele at MTHFR C667T with respect to cancer risk appeared to be stronger for boys than the girls (Table 3) but this difference was not statistically significant. The incidence of pediatric hematological malignancies worldwide has increased for boys but not for girls $[59,60]$. While the complete underlying mechanism has not been discovered, sex hormones and steroids reportedly play a part in the control of the proliferation of leukemic cells. Supporting the idea of gender differences in susceptibility to childhood ALL, it was found that 17-Bestrogen had a stronger inhibitory effect than testosterone on human monoblastic U937 cells [61]. In addition, the TT genotype at MTHFR C677T conferred higher 
plasma homocysteine levels than the CC genotype selectively in folate-dependent boys, which provides additional evidence for gender differences $[62,63]$.

In conclusion, this study documented the evidence of a relationship between the genotypes of MTHFR and childhood ALL risk and investigated age- and gender-interactions with the genotype to determine childhood ALL susceptibility. The presence of the T allele of C677T was not only a detectable and predictive biomarker for childhood ALL but also a protective determinant for older patients and boys.

\section{Author Contributions}

Conceived and designed the experiments: DTB CMH. Performed the experiments: WSC HXJ CLH CEM. Analyzed the data: JSP CMH CWT. Contributed reagents/materials/analysis tools: JSP YNH CWT. Wrote the paper: JSP DTB.

\section{References}

1. Kaatsch P (2010) Epidemiology of childhood cancer. Cancer Treat Rev 36: 277-285. doi: 10.1016/j. ctrv.2010.02.003 PMID: 20231056

2. Barry EV, Silverman LB (2008) Acute lymphoblastic leukemia in adolescents and young adults. Curr Hematol Malig Rep 3: 161-166. doi: 10.1007/s11899-008-0023-9 PMID: 20425461

3. Belson M, Kingsley B, Holmes A (2007) Risk factors for acute leukemia in children: a review. Environ Health Perspect 115: 138-145. PMID: 17366834

4. Zwaan CM, Reinhardt D, Hitzler J, Vyas $P$ (2010) Acute leukemias in children with Down syndrome. Hematol Oncol Clin North Am 24: 19-34. doi: 10.1016/j.hoc.2009.11.009 PMID: 20113894

5. Mathew CG (2006) Fanconi anaemia genes and susceptibility to cancer. Oncogene 25: 5875-5884. PMID: 16998502

6. Szczepanski T, Harrison CJ, van Dongen JJ (2010) Genetic aberrations in paediatric acute leukaemias and implications for management of patients. Lancet Oncol 11: 880-889. doi: 10.1016/S1470-2045 (09)70369-9 PMID: 20435517

7. Bailey LB, Gregory JR (1999) Polymorphisms of methylenetetrahydrofolate reductase and other enzymes: metabolic significance, risks and impact on folate requirement. J Nutr 129: 919-922. PMID: 10222379

8. Knock E, Deng L, Wu Q, Leclerc D, Wang XL, Rozen R (2006) Low dietary folate initiates intestinal tumors in mice, with altered expression of G2-M checkpoint regulators polo-like kinase 1 and cell division cycle 25c. Cancer Res 66: 10349-10356. PMID: 17079455

9. Van der Put NM, Gabreels F, Stevens EM, Smeitink JA, Trijbels FJ, Eskes TK, et al. (1998) A second common mutation in the methylenetetrahydrofolate reductase gene: an additional risk factor for neuraltube defects? AM J Hum Genet 62: 1044-1051. PMID: 9545395

10. Robien K, Ulrich CM (2003) 5,10-Methylenetetrahydrofolate reductase polymorphisms and leukemia risk: a HuGE minireview. Am J Epidemiol 157: 571-582. PMID: 12672676

11. Kang SS, Zhou J, Wong PW, Kowalisyn J, Strokosch G. (1988) Intermediate homocysteinemia: a thermolabile variant of methylenetetrahydrofolate reductase. AM J Hum Genet 43: 414-421. PMID: 3177384

12. Homberger A, Linnebank M, Winter C, Willenbring H, Marquardt T, Harms E, et al. (2000) Genomic structure and transcript variants of the human methylenetetrahydrofolate reductase gene. Eur J Hum Genet 8: 725-729. PMID: 10980581

13. Sohn KJ, Croxford R, Yates Z, Lucock M, Kim YI (2004) Effect of the methylenetetrahydrofolate reductase C677T polymorphism on chemosensitivity of colon and breast cancer cells to 5 -fluorouracil and methotrexate. J Natl Cancer Inst 96: 134-144. PMID: 14734703

14. Teng Z, Wang L, Cai S, Yu P, Wang J, Gong J, et al. (2013) The 677C >T (rs1801133) polymorphism in the MTHFR gene contributes to colorectal cancer risk: a meta-analysis based on 71 research studies. PLoS One 8: e55332. doi: 10.1371/journal.pone.0055332 PMID: 23437053

15. Yu L, Chen J (2012) Association of MTHFR Ala222Val (rs1801133) polymorphism and breast cancer susceptibility: An update meta-analysis based on 51 research studies. Diagn Pathol 7: 171. doi: 10. 1186/1746-1596-7-171 PMID: 23217001

16. Jia J, Ma Z, Wu S (2011) Positive association between MTHFR C677T polymorphism and oral cancer risk: a meta-analysis. Tumour Biol 35: 4943-4948. 
17. Tsai CW, Hsu CF, Tsai MH, Tsou YA, Hua CH, Chang WS, et al. (2011) Methylenetetrahydrofolate reductase (MTHFR) genotype, smoking habit, metastasis and oral cancer in Taiwan. Anticancer Res 31: 2395-2399. PMID: 21737671

18. Liu ZB, Wang LP, Shu J, Jin C, Lou ZX (2013) Methylenetetrahydrofolate reductase 677TT genotype might be associated with an increased lung cancer risk in Asians. Gene 515: 214-219. doi: 10.1016/j. gene.2012.11.036 PMID: 23237779

19. Skibola CF, Smith MT, Kane E, Roman E, Rollinson S, Cartwright RA, et al. (1999) Polymorphisms in the methylenetetrahydrofolate reductase gene are associated with susceptibility to acute leukemia in adults. Proc Natl Acad Sci U S A 96: 12810-12815. PMID: 10536004

20. Matsuo K, Suzuki R, Hamajima N, Ogura M, Kagami Y, Taji H, et al. (2001) Association between polymorphisms of folate- and methionine-metabolizing enzymes and susceptibility to malignant lymphoma. Blood 97: 3205-3209. PMID: 11342450

21. Franco RF, Simoes BP, Tone LG, Gabellini SM, Zago MA, Falcao RP (2001) The methylenetetrahydrofolate reductase $\mathrm{C677T}$ gene polymorphism decreases the risk of childhood acute lymphocytic leukaemia. Br J Haematol 115: 616-618. PMID: 11736945

22. Wiemels JL, Smith RN, Taylor GM, Eden OB, Alexander FE, Greaves MF (2001) Methylenetetrahydrofolate reductase (MTHFR) polymorphisms and risk of molecularly defined subtypes of childhood acute leukemia. Proc Natl Acad Sci U S A 98: 4004-4009. PMID: 11274424

23. Wu KH, Wang CH, Yang YL, Peng CT, Lin WD, Tsai FJ (2010) Significant association of XRCC4 single nucleotide polymorphisms with childhood leukemia in Taiwan. Anticancer Res 30: 529-533. PMID: 20332465

24. Bau DT, Tsai CW, Lin CC, Tsai RY, Tsai MH (2011) Association of Alpha B-Crystallin genotypes with oral cancer susceptibility, survival, and recurrence in Taiwan. PLoS One 6: e16374. doi: 10.1371/ journal.pone.0016374 PMID: 21915251

25. Wu HC, Chang CH, Tsai RY, Lin CH, Wang RF, Tsai CW, et al. (2010) Significant association of methylenetetrahydrofolate reductase single nucleotide polymorphisms with prostate cancer susceptibility in Taiwan. Anticancer Res 30: 3573-3577. PMID: 20944139

26. Kang S, Kim JW, Kang GH, Park NH, Song YS, Kang SB, et al. (2005) Polymorphism in folate- and methionine-metabolizing enzyme and aberrant $\mathrm{CpG}$ island hypermethylation in uterine cervical cancer. Gynecol Oncol 96: 173-180. PMID: 15589597

27. Liu CS, Tsai CW, Hsia TC, Wang RF, Liu CJ, Hang LW, et al. (2009) Interaction of methylenetetrahydrofolate reductase genotype and smoking habit in Taiwanese lung cancer patients. Cancer Genomics Proteomics 6: 325-329. PMID: 20065319

28. Milne E, Royle JA, Miller M, Bower C, de Klerk NH, Bailey HD, et al. (2010) Maternal folate and other vitamin supplementation during pregnancy and risk of acute lymphoblastic leukemia in the offspring. Int $J$ Cancer 126: 2690-2699. doi: 10.1002/ijc.24969 PMID: 19839053

29. Chan JY, Ugrasena DG, Lum DW, Lu Y, Yeoh AE (2011) Xenobiotic and folate pathway gene polymorphisms and risk of childhood acute lymphoblastic leukaemia in Javanese children. Hematol Oncol 29: 116-123. doi: 10.1002/hon.965 PMID: 20824655

30. Damnjanovic T, Milicevic R, Novkovic T, Jovicic O, Bunjevacki V, Jekic B, et al. (2010) Association between the methylenetetrahydrofolate reductase polymorphisms and risk of acute lymphoblastic leukemia in Serbian children. J Pediatr Hematol Oncol 32: e148-150. doi: 10.1097/MPH Ob013e3181cbd252 PMID: 20445408

31. Tong N, Fang Y, Li J, Wang M, Lu Q, Wang S, et al. (2010) Methylenetetrahydrofolate reductase polymorphisms, serum methylenetetrahydrofolate reductase levels, and risk of childhood acute lymphoblastic leukemia in a Chinese population. Cancer Sci 101: 782-786. doi: 10.1111/j.1349-7006.2009. 01429.x PMID: 20002681

32. de Jonge R, Tissing WJ, Hooijberg JH, Jansen G, Kaspers GJ, Lindemans J, et al. (2009) Polymorphisms in folate-related genes and risk of pediatric acute lymphoblastic leukemia. Blood 113: 2284-2289. doi: 10.1182/blood-2008-07-165928 PMID: 19020309

33. Kamel AM, Moussa HS, Ebid GT, Bu RR, Bhatia KG (2007) Synergistic effect of methyltetrahydrofolate reductase (MTHFR) C677T and A1298C polymorphism as risk modifiers of pediatric acute lymphoblastic leukemia. J Egypt Natl Canc Inst 19: 96-105. PMID: 19034339

34. Chatzidakis K, Goulas A, Athanassiadou-Piperopoulou F, Fidani L, Koliouskas D, Mirtsou V (2006) Methylenetetrahydrofolate reductase C677T polymorphism: association with risk for childhood acute lymphoblastic leukemia and response during the initial phase of chemotherapy in greek patients. Pediatr Blood Cancer 47: 147-151. PMID: 16123993

35. Zanrosso CW, Hatagima A, Emerenciano M, Ramos F, Figueiredo A, Felix TM, et al. (2006) The role of methylenetetrahydrofolate reductase in acute lymphoblastic leukemia in a Brazilian mixed population. Leuk Res 30: 477-481. doi: 10.1016/j.leukres.2009.01.019 PMID: 16182363 
36. Krajinovic M, Lamothe S, Labuda D, Lemieux-Blanchard E, Theoret $Y$, Moghrabi A, et al. (2004) Role of MTHFR genetic polymorphisms in the susceptibility to childhood acute lymphoblastic leukemia. Blood 103: 252-257. PMID: 12958073

37. Silva RM, Fontes AC, Silva KA, Sant'Ana TA, Ramos FJ, Marques-Salles Tde J, et al. (2013) Polymorphisms involved in folate metabolism pathways and the risk of the development of childhood acute leukemia. Genet Test Mol Biomarkers 17: 147-152. doi: 10.1089/gtmb.2012.0174 PMID: 23336575

38. Sood S, Das R, Trehan A, Ahluwalia J, Sachdeva MU, Varma N, et al. (2010) Methylenetetrahydrofolate reductase gene polymorphisms: association with risk for pediatric acute lymphoblastic leukemia in north Indians. Leuk Lymphoma 51: 928-932. doi: 10.3109/10428191003719023 PMID: 20367562

39. Reddy H, Jamil K (2006) Polymorphisms in the MTHFR gene and their possible association with susceptibility to childhood acute lymphocytic leukemia in an Indian population. Leuk Lymphoma 47: 1333-1339. PMID: 16923565

40. Amigou A, Rudant J, Orsi L, Goujon-Bellec S, Leverger G, Baruchel A, et al. (2012) Folic acid supplementation, MTHFR and MTRR polymorphisms, and the risk of childhood leukemia: the ESCALE study (SFCE). Cancer Causes Control 23: 1265-1277. doi: 10.1007/s10552-012-0004-0 PMID: 22706675

41. Azhar MR, Rahimi Z, Vaisi-Raygani A, Akramipour R, Madani H, Rahimi Z, et al. (2012) Lack of association between MTHFR C677T and A1298C polymorphisms and risk of childhood acute lymphoblastic leukemia in the Kurdish population from Western Iran. Genet Test Mol Biomarkers 16: 198-202. doi: 10.1089/gtmb.2011.0041 PMID: 22017305

42. Nikbakht M, MalekZadeh K, Kumar Jha A, Askari M, Marwaha RK, Kaul D, et al. (2012) Polymorphisms of MTHFR and MTR genes are not related to susceptibility to childhood ALL in North India. Exp Oncol 34: 43-48. PMID: 22453148

43. Metayer C, Scelo G, Chokkalingam AP, Barcellos LF, Aldrich MC, Chang JS, et al. (2011) Genetic variants in the folate pathway and risk of childhood acute lymphoblastic leukemia. Cancer Causes Control 22: 1243-1258. doi: 10.1007/s10552-011-9795-7 PMID: 21748308

44. Lightfoot TJ, Johnston WT, Painter D, Simpson J, Roman E, Skibola CF, et al. (2010) Genetic variation in the folate metabolic pathway and risk of childhood leukemia. Blood 115: 3923-3929. doi: 10.1182/ blood-2009-10-249722 PMID: 20101025

45. Sadananda Adiga MN, Chandy S, Ramachandra N, Appaji L, Aruna Kumari BS, Ramaswamy G, et al. (2010) Methylenetetrahydrofolate reductase gene polymorphisms and risk of acute lymphoblastic leukemia in children. Indian J Cancer 47: 40-45. doi: 10.4103/0019-509X.58858 PMID: 20071789

46. Yeoh AE, Lu Y, Chan JY, Chan YH, Ariffin H, Kham SK, et al. (2010) Genetic susceptibility to childhood acute lymphoblastic leukemia shows protection in Malay boys: results from the Malaysia-Singapore ALL Study Group. Leuk Res 34: 276-283. doi: 10.1016/j.leukres.2009.07.003 PMID: 19651439

47. Alcasabas $P$, Ravindranath $Y$, Goyette G, Haller A, Del Rosario L, Lesaca-Medina MY, et al. (2008) 5,10-methylenetetrahydrofolate reductase (MTHFR) polymorphisms and the risk of acute lymphoblastic leukemia (ALL) in Filipino children. Pediatr Blood Cancer 51: 178-182. doi: 10.1002/pbc.21511 PMID: 18421714

48. Petra BG, Janez J, Vita D (2007) Gene-gene interactions in the folate metabolic pathway influence the risk for acute lymphoblastic leukemia in children. Leuk Lymphoma 48: 786-792. PMID: 17454638

49. Kim NK, Chong SY, Jang MJ, Hong SH, Kim HS, Cho EK, et al. (2006) Association of the methylenetetrahydrofolate reductase polymorphism in Korean patients with childhood acute lymphoblastic leukemia. Anticancer Res 26: 2879-2881. PMID: 16886608

50. Oliveira E, Alves S, Quental S, Ferreira F, Norton L, Costa V, et al. (2005) The MTHFR C677T and A1298C polymorphisms and susceptibility to childhood acute lymphoblastic leukemia in Portugal. J Pediatr Hematol Oncol 27: 425-429. PMID: 16096524

51. Schnakenberg E, Mehles A, Cario G, Rehe K, Seidemann K, Schlegelberger B, et al. (2005) Polymorphisms of methylenetetrahydrofolate reductase (MTHFR) and susceptibility to pediatric acute lymphoblastic leukemia in a German study population. BMC Med Genet 6: 23. PMID: 15921520

52. Thirumaran RK, Gast A, Flohr T, Burwinkel B, Bartram C, Hemminki K, et al. (2005) MTHFR genetic polymorphisms and susceptibility to childhood acute lymphoblastic leukemia. Blood 106: 2590-2591; author reply 2591-2592. PMID: 16172254

53. Balta G, Yuksek N, Ozyurek E, Ertem U, Hicsonmez G, Altay C, et al. (2003) Characterization of MTHFR, GSTM1, GSTT1, GSTP1, and CYP1A1 genotypes in childhood acute leukemia. Am J Hematol 73: 154-160. PMID: 12827651

54. Li X, Liao Q, Zhang S, Chen M (2014) Association of methylenetetrahytrofolate reductase (MTHFR) C677T and A1298C polymorphisms with the susceptibility of childhood acute lymphoblastic leukaemia (ALL) in Chinese population. Eur J Med Res 19: 5. doi: 10.1186/2047-783X-19-5 PMID: 24476575 
55. Yan J, Yin M, Dreyer ZE, Scheurer ME, Kamdar K, Wei Q, et al. (2012) A meta-analysis of MTHFR C677T and A1298C polymorphisms and risk of acute lymphoblastic leukemia in children. Pediatr Blood Cancer 58: 513-518. doi: 10.1002/pbc.23137 PMID: 21495160

56. Jiang Y, Hou J, Zhang Q, Jia ST, Wang BY, Zhang JH, et al. (2013) The MTHFR C677T polymorphism and risk of acute lymphoblastic leukemia: an updated meta-analysis based on 37 case-control studies. Asian Pac J Cancer Prev 14: 6357-6362. PMID: 24377532

57. Narayanan S, McConnell J, Little J, Sharp L, Piyathilake CJ, Powers H, et al. (2004) Associations between two common variants $\mathrm{C} 677 \mathrm{~T}$ and $\mathrm{A} 1298 \mathrm{C}$ in the methylenetetrahydrofolate reductase gene and measures of folate metabolism and DNA stability (strand breaks, misincorporated uracil, and DNA methylation status) in human lymphocytes in vivo. Cancer Epidemiol Biomarkers Prev 13: 1436-1443. PMID: 15342443

58. Pereira AC, Schettert IT, Morandini Filho AA, Guerra-Shinohara EM, Krieger JE (2004) Methylenetetrahydrofolate reductase (MTHFR) c677t gene variant modulates the homocysteine folate correlation in a mild folate-deficient population. Clin Chim Acta 340: 99-105. PMID: 14734201

59. Cartwright RA, Gurney KA, Moorman AV (2002) Sex ratios and the risks of haematological malignancies. Br J Haematol 118: 1071-1077. PMID: 12199787

60. Pearce MS, Parker $L$ (2001) Childhood cancer registrations in the developing world: still more boys than girls. Int J Cancer 91: 402-406. PMID: 11169966

61. Mossuz P, Cousin F, Castinel A, Chauvet M, Sotto MF, Polack B, et al. (1998) Effects of two sex steroids (17beta estradiol and testosterone) on proliferation and clonal growth of the human monoblastic leukemia cell line, U937. Leuk Res 22: 1063-1072. PMID: 9783810

62. Papoutsakis C, Yiannakouris N, Manios Y, Papaconstantinou E, Magkos F, Schulpis KH, et al. (2006) The effect of MTHFR(C677T) genotype on plasma homocysteine concentrations in healthy children is influenced by gender. Eur J Clin Nutr 60: 155-162. PMID: 16234842

63. Dierkes J, Jeckel A, Ambrosch A, Westphal S, Luley C, Boeing H (2001) Factors explaining the difference of total homocysteine between men and women in the European Investigation Into Cancer and Nutrition Potsdam study. Metabolism 50: 640-645. PMID: 11398138 